\title{
Sustained virologic response and IL28B single-nucleotide polymorphisms in patients with chronic hepatitis C treated with pegylated interferon alfa and ribavirin
}

\section{Elżbieta Jabłonowska1凶 ${ }^{1 凶}$, Anna Piekarska1', Ewa Koślińska-Berkan¹, Aleksandra Omulecka², Bożena Szymańska ${ }^{3}$ and Kamila Wójcik ${ }^{1}$ \\ 1Department of Infectious Diseases and Hepatology, 2Department of Pathology, ${ }^{3}$ Central Laboratory of the Medical University of Łódź, Łódź, Poland}

Introduction. Hepatitis C virus (HCV) infection is a global health problem which can lead to liver cirrhosis or hepatocellular carcinoma in one-fifth of chronically infected patients. Materials and methods. The study group consisted of 123 patients: 90 with HCV mono- and 33 with HIV/HCV co-infection, who were treated with pegylated interferon alfa (Peg-IFN-a) and ribavirin. We analyzed selected pretreatment factors: age, sex, HIV/ HCV co-infection, grade of inflammation, necrotic changes and fibrosis in histological analysis of liver bioptates, HCV viral load, HCV genotypes, and single nucleotide polymorphisms (SNPs) of IL28B and tried to find out which of them influence sustained virological response (SVR). The IL28B SNP C/T (rs12979860) was analyzed using Custom ${ }^{\circledR}$ SNP Genotyping Assays (Applied Biosystems). Results. Multivariate analysis demonstrated that after adjusting for the other variables three predictors independently influence SVR, namely genotype 3 of $\mathrm{HCV}$, presence of the CC genotype and age $>40$ years (OR respectively $15.14,3.62$, and 0.36 ). HCV mono-infected patients were infected with HCV genotype 3 or 4 less frequently $(p=0.0001)$ compared to $\mathrm{HIV} / \mathrm{HCV}$ co-infected individuals. In patients with HIV/HCV co-infection the CC variant occurred more frequently whereas $C T$ was found less frequently ( $p=0.001, p=0.0146$, respectively). In patients with HIV/HCV co-infection, 3 and 4 genotype of HCV occurred more frequently compared to patients with HCV mono-infection $(p=0.0001)$. Conclusions. These data suggest that age, HCV genotype and IL28B polymorphism are useful for prediction of the response to treatment with PegIFN- $\alpha$ and ribavirin. The more frequent occurrence of HCV genotypes 3 or 4 in patients with HIV/HCV co-infection could be associated with the route of transmission.

Key words: HIV, HCV, IL28B, interferon, ribavirin, sustained virologic response

Received: 28 December, 2011; revised: 18 May, 2012; accepted:

17 July, 2012; available on-line: 27 August, 2012

\section{INTRODUCTION}

WHO estimates that $3 \%$ of the world population is infected with hepatitis $C$ virus and 3-4 million new infections occur every year (WHO) (Chen \& Morgan,
2006). Approximately $80 \%$ of patients with acute hepatitis $\mathrm{C}$ fail to eliminate the virus and become chronically infected (Lauer \& Walker, 2001). It is estimated that one out of five chronically infected persons develops cirrhosis after 20 years from the infection (Koziel \& Peters, 2007). Up till now Peg-IFN- $\alpha$ and ribavirin have been a standard treatment in hepatitis $\mathrm{C}$ virus infections, however this therapy does not eliminate HCV in approximately half of the treated patients infected with HCV genotype 1 or 4 (Fried \& Hadziyannis, 2004). In the near future the addition of direct-acting antivirals (DAAs) to the Peg-IFN and ribavirin (RBV) will become a routine practice. Recently two new drugs for hepatitis C, boceprevir (made by Merck) and telaprevir (made by Vertex Pharmaceuticals), have been approved by FDA (Pockros, 2011). Although both boceprevir and telaprevir promise a better chance of a cure, they have to be administered together with IFN and ribavirin, are very expensive and have potentially serious side effects. Currently the treatment of chronic hepatitis is inclined towards individualized therapy, based on the knowledge of factors predicting response to treatment.

Great progress has been achieved thanks to the recent discovery through a genome-wide association study (GWAS), that a single nucleotide polymorphism (SNP) near the IL $28 \mathrm{~B}$ gene can predict the response to hepatitis $\mathrm{C}$ treatment with interferon and ribavirin (Ge et al., 2009; Suppiah et al., 2009; Tanaka et al., 2009).

In our present study we analyzed the results of the combined therapy with Peg-IFN and ribavirin in $\mathrm{HCV}$ mono-infected and $\mathrm{HIV} / \mathrm{HCV}$ co-infected patients in our center. We compared these two populations of patients, focusing on the analysis of prognostic factors for SVR with regard to the $\mathrm{C} / \mathrm{T}$ polymorphism near the IL 28B gene.

\section{MATERIALS AND METHODS}

The study group consisted of 123 patients: 90 with $\mathrm{HCV}$ mono- and 33 with $\mathrm{HIV} / \mathrm{HCV}$ co-infection, who were treated in our center from 2006 through 2010. In all the patients treatment with Peg-IFN- $\alpha$ and ribavirin was the first chronic hepatitis C therapy. Patients were

e-mail: elajablonowska@gmail.com

Abbreviations: CART, combination antiretroviral therapy; $\mathrm{CHC}$, chronic hepatitis C; DAAs, direct-acting antivirals; HCV , hepatitis $C$ virus; HIV, human immunodeficiency virus; GWAS, genome-wide association study; IL28B, Interleukin-28B; Peg-IFN-a, pegylated interferon-alpha; $R B V$, ribavirin; SNP, single-nucleotide polymorphism; SVR, sustained virologic response 
Table 1. Comparison between patients with HIV/HCV co-infection and with HCV mono-infection

\begin{tabular}{|c|c|c|c|c|c|}
\hline & \multicolumn{2}{|l|}{$\mathrm{HIV} / \mathrm{HCV}$} & \multicolumn{2}{|l|}{$\mathrm{HCV}$} & \multirow[t]{2}{*}{$p$ value } \\
\hline & N/Total & $\%$ & N/Total & $\%$ & \\
\hline Women & $17 / 33$ & 51.51 & $34 / 90$ & 37.78 & $>0.05$ \\
\hline Men & $16 / 33$ & 48.48 & $56 / 90$ & 62.22 & \\
\hline $\begin{array}{l}\text { HCV viremia } \\
>600000 \mathrm{IU} / \mathrm{ml}\end{array}$ & $12 / 33$ & 36.36 & $33 / 88$ & 37.50 & $>0.05$ \\
\hline $\mathrm{G} \leq 2$ & $28 / 31$ & 90.32 & $71 / 89$ & 79.78 & $>0.05$ \\
\hline $\mathrm{S} \leq 2$ & $27 / 31$ & 87.10 & $64 / 89$ & 71.91 & $>0.05$ \\
\hline Liver cirrhosis & $1 / 31$ & 3.22 & $7 / 89$ & 7.87 & $>0.05$ \\
\hline Genotype 1 & $8 / 33$ & 24.24 & $79 / 90$ & 87.78 & $=0.0001$ \\
\hline Genotype 3 & $12 / 33$ & 36.36 & $7 / 90$ & 7.78 & $=0.0001$ \\
\hline Genotype 4 & $13 / 33$ & 39.39 & $4 / 90$ & 4.44 & $=0.0001$ \\
\hline $\mathrm{CC}$ & $17 / 33$ & 51.52 & $19 / 90$ & 21.11 & $=0.001$ \\
\hline $\mathrm{CT}$ & $12 / 33$ & 36.36 & $55 / 90$ & 62.22 & $=0.0146$ \\
\hline$\pi$ & $4 / 33$ & 12.12 & $16 / 90$ & 16.67 & $>0.05$ \\
\hline Age $>40$ years & $4 / 33$ & 12.12 & $40 / 90$ & 44.44 & $=0.0009$ \\
\hline Age $^{*}$ years & \multicolumn{2}{|l|}{$32(29-37)$} & \multicolumn{2}{|c|}{$33.5(22-49)$} & $>0.05$ \\
\hline HCV viral load* $\left(x 10^{6}\right) \mathrm{IU} / \mathrm{ml}$ & \multicolumn{2}{|l|}{$2.78(0.38-4.8)$} & \multicolumn{2}{|c|}{$2.78(0.368-5.78)$} & $>0.05$ \\
\hline
\end{tabular}

*median (lower quartile-upper quartile)

Table 2. Comparison between patients with SVR and without SVR

\begin{tabular}{|c|c|c|c|c|c|}
\hline \multirow{2}{*}{ Respondent characteristic } & \multicolumn{2}{|l|}{ SVR } & \multicolumn{2}{|c|}{ Without SVR } & \multirow{2}{*}{$p$ value } \\
\hline & N/Total & $\%$ & N/Total & $\%$ & \\
\hline Women & $30 / 72$ & 41.67 & $21 / 51$ & 41.18 & $>0.05$ \\
\hline Men & $42 / 72$ & 58.33 & $30 / 51$ & 58.82 & \\
\hline Viral load >600000 IU/ml & $45 / 72$ & 62.5 & $31 / 51$ & 60.78 & $>0.05$ \\
\hline Viral load $\leq 600000 \mathrm{IU} / \mathrm{ml}$ & $27 / 72$ & 37.5 & $20 / 51$ & 39.22 & \\
\hline $\mathrm{HIV} / \mathrm{HCV}$ & $23 / 72$ & 31.94 & $10 / 51$ & 19.61 & $>0.05$ \\
\hline $\mathrm{HCV}$ & $49 / 72$ & 68.06 & $41 / 51$ & 80.39 & \\
\hline $\begin{array}{l}\text { Liver cirrhosis } \\
\text { Without liver cirrhosis }\end{array}$ & $\begin{array}{l}3 / 70 \\
67 / 70\end{array}$ & $\begin{array}{l}4.29 \\
95.71\end{array}$ & $\begin{array}{l}5 / 50 \\
45 / 50\end{array}$ & $\begin{array}{l}10.00 \\
90.00\end{array}$ & $>0.05$ \\
\hline $\begin{array}{l}G>2 \\
G \leq 2\end{array}$ & $\begin{array}{l}11 / 70 \\
59 / 70\end{array}$ & $\begin{array}{l}15.71 \\
84.29\end{array}$ & $\begin{array}{l}10 / 50 \\
40 / 50\end{array}$ & $\begin{array}{l}20.00 \\
80.00\end{array}$ & $>0.05$ \\
\hline $\begin{array}{l}\mathrm{S}>2 \\
\mathrm{~S} \leq 2\end{array}$ & $\begin{array}{l}15 / 70 \\
55 / 70\end{array}$ & $\begin{array}{l}21.43 \\
78.57\end{array}$ & $\begin{array}{l}14 / 50 \\
36 / 50\end{array}$ & $\begin{array}{l}28.00 \\
72.00\end{array}$ & $>0.05$ \\
\hline $\begin{array}{l}\text { Genotyp } 1 \\
\text { not Genotype } 1\end{array}$ & $\begin{array}{l}42 / 72 \\
30 / 72\end{array}$ & $\begin{array}{l}58.33 \\
41.67\end{array}$ & $\begin{array}{l}45 / 51 \\
6 / 51\end{array}$ & $\begin{array}{l}88.24 \\
11.76\end{array}$ & $=0.0003$ \\
\hline $\begin{array}{l}\text { Genotype } 3 \\
\text { not Genotype } 3\end{array}$ & $\begin{array}{l}18 / 72 \\
54 / 72\end{array}$ & $\begin{array}{l}25.00 \\
75.00\end{array}$ & $\begin{array}{l}1 / 51 \\
50 / 51\end{array}$ & $\begin{array}{l}1.96 \\
98.04\end{array}$ & $=0.0005$ \\
\hline $\begin{array}{l}\text { Genotype } 4 \\
\text { not Genotype } 4\end{array}$ & $\begin{array}{l}12 / 72 \\
60 / 72\end{array}$ & $\begin{array}{l}16.67 \\
83.33\end{array}$ & $\begin{array}{l}5 / 51 \\
46 / 51\end{array}$ & $\begin{array}{l}9.80 \\
90.20\end{array}$ & $>0.05$ \\
\hline $\begin{array}{l}\mathrm{CC} \\
\text { not } \mathrm{CC}\end{array}$ & $\begin{array}{l}28 / 72 \\
44 / 72\end{array}$ & $\begin{array}{l}38.89 \\
61.11\end{array}$ & $\begin{array}{l}8 / 51 \\
43 / 51\end{array}$ & $\begin{array}{l}15.69 \\
84.31\end{array}$ & $=0.0053$ \\
\hline $\begin{array}{l}\mathrm{CT} \\
\text { not } \mathrm{CT}\end{array}$ & $\begin{array}{l}34 / 72 \\
38 / 72\end{array}$ & $\begin{array}{l}47.22 \\
52.78\end{array}$ & $\begin{array}{l}33 / 51 \\
18 / 51\end{array}$ & $\begin{array}{l}64.71 \\
35.29\end{array}$ & $>0.05$ \\
\hline $\begin{array}{l}\text { Tा } \\
\text { not TT }\end{array}$ & $\begin{array}{l}10 / 72 \\
62 / 72\end{array}$ & $\begin{array}{l}13.89 \\
86.11\end{array}$ & $\begin{array}{l}10 / 51 \\
41 / 51\end{array}$ & $\begin{array}{l}19.61 \\
80.39\end{array}$ & $>0.05$ \\
\hline $\begin{array}{l}\text { Age }>40 \text { years } \\
\text { Age } \leq 40 \text { years }\end{array}$ & $\begin{array}{l}18 / 72 \\
54 / 72\end{array}$ & $\begin{array}{l}25.00 \\
75.00\end{array}$ & $\begin{array}{l}26 / 51 \\
25 / 51\end{array}$ & $\begin{array}{l}50.98 \\
49.02\end{array}$ & $=0.0031$ \\
\hline
\end{tabular}


considered eligible for this study if they fulfilled the following inclusion criteria.

Patients finished the treatment with Peg-IFN- $\alpha$ and ribavirin at least 6 months earlier.

The treatment was conducted according to the protocol described below.

Combined therapy using Peg-IFN- $\alpha$ 2a (Pegasys; Roche, Switzerland) or Peg-IFN- $\alpha$ 2b (PEGIntron; Schering Corp) and ribavirin was applied. Peg-IFN- $\alpha$ was administered subcutaneously once a week in a standard dose (Pegasys dose of $180 \mu \mathrm{g}$, PEGIntron dose dependent on the patient's weight). Ribavirin was administered per os daily in a dose dependent on the patient's weight (less than $60 \mathrm{~kg}-1000 \mathrm{mg}$, above $60 \mathrm{~kg}-1200 \mathrm{mg}$ ). The decision to continue the therapy or not was made 12 weeks after its beginning. Patients with undetectable $\mathrm{HCV}$ viremia continued the therapy until 24 or 48 weeks (genotype 3-24 weeks, genotype 1 or 4-48 weeks). In patients with a decrease in viral load of less than 2 log the therapy was discontinued. In patients with a decrease in viral load exceeding $2 \log$ the therapy was continued - for genotype 3 until 24 week, for genotypes 1 and 4 until 48 weeks if the viral load at 24 week was undetectable.

The treatment was not discontinued due to side effects and during the therapy patients turned up at all appointed visits.

$\mathrm{HCV}$ viremia was assessed 6 months after the end of the treatment.

On introduction of Peg-IFN- $\alpha$ with ribavirin patients with $\mathrm{HIV} / \mathrm{HCV}$ co-infection had to receive antiretroviral treatment, had undetectable HIV viremia (<50 copies/ $\mathrm{ml}$ ) and CD4 count higher than 350 cells $/ \mu \mathrm{l}$.

Before the treatment liver biopsy was performed in almost all patients (120 persons). The grade of inflammation and necrotic changes as well as stage of fibrosis were assessed according to the Batt and Ludwig's scale (Batts \& Ludwig, 1995).

In all the patients who fulfilled the abovementioned criteria the IL $28 \mathrm{~B}$ single-nucleotide polymorphism C/T (rs12979860) was analysed..

Genomic DNA were isolated from $200 \mu \mathrm{l}$ of blood using the QIAamp DNA Blood Mini Kit (Qiagen) according to the manufacturer's protocol. DNA was quantified using a PicoDrop spectrophotometer (Picodrop). The IL $28 B$ single-nucleotide polymorphism C/T (rs12979860) was analysed using Custom ${ }^{\circledR}$ SNP Genotyping Assays (Applied Biosystems). Primer and probe sequences were: Forward Primer 5'-GCCTGTCGTGTACTGAACCA, Reverse Primer 5'-GCGCGGAGTGCAATTCAAC, Probe (C allele) 5'-VIC-TGGTTCGCGCCTTC, Probe (T allele) 5'-FAM-CTGGTTCACGCCTTC. Genotyping was performed using an ABI7900HT Real-Time PCR System (Applied Biosystems) in $25 \mu$ reaction volume containing $10 \mathrm{ng}$ DNA, 12.5 $\mu \mathrm{T} \mathrm{TaqMan}{ }^{\circledR}$ Universal PCR Master Mix and $1.25 \mu \mathrm{l}$ (40x) Custom ${ }^{\circledR}$ SNP Genotyping Assays and analysed using Sequence Detection System 2.3 Software.

Statistical Methods. Average values and standard deviation of quantitative traits were calculated for parameters with normal distribution. Variables that were not normally distributed were expressed as median (lower-upper quartiles). These variables were compared according to the Mann-Whitney test. To compare categorical variables between groups we used: Chi-square distribution, Yates' correction for continuity or Fisher's exact test (according to the size of the studied group). Multivariate logistic regression was used to determine whether SVR was related to selected predictors.
Table 3. Multivariate analyses for chosen parameters and SVR

\begin{tabular}{|c|c|c|c|}
\hline \multirow{2}{*}{ Respondent characteristic } & \multicolumn{2}{|c|}{ Adjusted odds ratio } & \multirow{2}{*}{$p$ value } \\
\hline & Ratio & $95 \% \mathrm{Cl}$ & \\
\hline Gender & 1.07 & $0.44-2.57$ & $>0.05$ \\
\hline Age $>40$ years & 0.36 & $0.13-0.99$ & $=0.0478$ \\
\hline$G>2$ & 1.45 & $0.35-6.00$ & $>0.05$ \\
\hline$S>2$ & 0.64 & $0.17-2.35$ & $>0.05$ \\
\hline Genotype 3 & 15.14 & $1.78-128.85$ & $=0.0129$ \\
\hline Viral load $>600000 \mathrm{IU} / \mathrm{ml}$ & 1.37 & $0.57-3.28$ & $>0.05$ \\
\hline $\mathrm{CC}$ & 3.62 & $1.28-10.26$ & $=0.0155$ \\
\hline
\end{tabular}

\section{RESULTS}

The study group consisted of 123 Caucasian patients with chronic hepatitis C, out of whom 33 were HIV/ $\mathrm{HCV}$ co-infected.

Among the patients with $\mathrm{HIV} / \mathrm{HCV}$ co-infection 30 were HIV-infected through intravenous drug use, three through heterosexual contacts (out of whom two had sex with intravenous drug users). None of the HCV mono-infected patients declared even an incidental intravenous drug usage.

In the HIV/HCV co-infected patients infection with genotype 3 or 4 of hepatitis $C$ virus was observed more frequently and infection with genotype 1 less frequently compared to patients with HCV mono-infection $(p=0.0001)$. In patients with $\mathrm{HIV} / \mathrm{HCV}$ co-infection the CC polymorphism occurred more frequently whereas CT less frequently than in the mono-infected ones $(p=0.001$, $p=0.0146$ ) (Table 1).

Patients with the CC genotype did not differ from other patients before the treatment in the level of viremia, grade of inflammation and necrotic changes, stage of fibrosis in histopathological examination of bioptates, or the occurrence of various genotypes of the $\mathrm{HCV}$ virus (Table 2). In contrast, the CC genotype occurred more frequently in patients with $\mathrm{HIV} / \mathrm{HCV}$ coinfection compared to patients with $\mathrm{HCV}$ mono-infection $(16 / 33$ vs $20 / 90-p=0.005)$.

Patients with good response to treatment were characterised by younger age at the moment of the treatment introduction (more frequently below 40 years of age) as well as a more frequent occurrence of the CC genotype. Moreover, in patients with SVR the infection with genotype 1 occurred less frequently and with genotype 3 more frequently than in patients without SVR. Multivariate analysis demonstrated that after adjusting for the other variables 3 predictors independently influence SVR the presence of CC polymorphism, genotype 3 of $\mathrm{HCV}$ and age less than 40 years (Table 3).

\section{DISCUSSION}

To achieve optimal virologic response and good tolerability, individualized treatment with Peg-IFN and ribavirin is attempted. There are many pretreatment factors such as age, sex, ethnicity, body mass index, insulin resistance, hepatic steatosis, degree of liver fibrosis, HCV genotype, baseline viral load and viral kinetics during treatment which can influence the response to the therapy with Peg-IFN and ribavirin in patients with chronic hepatitis C (CHC) (Idrees \& Riazuddin S, 2009; Reddy 
et al., 2009; Aziz et al., 2011; Eslam et al., 2011). Out of these factors the HCV genotype is known as the strongest predictor of SVR and thus exerts a considerable influence on the decision regarding the duration of treatment (Hadziyannis et al., 2004; Navaneethan et al., 2009). Recently, four genome-wide association studies (GWAS) have identified single nucleotide polymorphisms (SNPs) near the IL $28 B$ gene (encoding IFN- $\lambda 3$ ) to be strongly associated with spontaneous and treatment-induced clearance of $\mathrm{HCV}$ infection in patients with genotype $1 \mathrm{HCV}$ (Ge et al., 2009; Suppiah et al., 2009; Tanaka et al., 2009; Rauch A et al., 2010). Ge and colleagues conducted a GWAS analysis of more than 1000 patients with genotype 1 . Using the Illumina Human $610^{\circledR}$ quad bead chip, the authors demonstrated that the probability of achieving SVR in patients bearing CC in the position rs12979860 in the 19 q13 region was double compared to those with CT/TT. Importantly from the clinical point of view, as many as approximately two-thirds of patients bearing the CC genotype (rs12979860) achieved SVR, while only less than a half of CT heterozygous and onethird of TT homozygous individuals could achieve SVR when treated with Peg-IFN and RBV (Ge et al., 2009). Pineda et al. (2010) reported rates of SVR according to the HCV genotype in patients with genotype CC and in those with genotype CT or T'T at, respectively, 50\% and $17 \%$ with genotype 1 and $93 \%$ and $77 \%$ with genotype 3. Similarly in our study SVR was achieved more frequently in patients with the CC genotype.

In contrast to unambiguous data on genotype $1 \mathrm{HCV}$ infection, the available data on IL-28B polymorphisms as predictors of SVR in patients with genotype 2 or $3 \mathrm{HCV}$ infection are conflicting. Mangia et al. (2010) showed that IL-28 variations play a minor role in the treatment outcome in patients with HCV genotype 2 or 3 (Mangia et al., 2010). In contrast, a study from Japan showed that the IL28B SNP genotype is an important predictive factor for SVR in patients with HCV genotypes $2 \mathrm{a}$ or $2 \mathrm{~b}$ (Kawaoka et al., 2011). In our study patients infected with HCV genotype 3 who had genotype CC for IL $28 B$ did not achieve SVR more frequently compared to patients infected with HCV genotype 3 who had genotypes CT or TT. However, it has to be emphasized that in present group only 19 patients were infected with HCV genotype 3 , out of whom eight had the IL 28 B CC genotype.

The distribution of the IL28B variants in patients infected with various HCV genotypes is also different. McCarthy et al. (2010) showed that the CC genotype at rs12979860 occurs more frequently in patients infected with HCV genotype 3 and patients infected with this genotype had a higher $\mathrm{HCV}$ viremia. In a German cohort the rs12979860 CC genotype was found in $42.7 \%$ of $\mathrm{HCV}$ genotype 2 or 3 patients, in $33.9 \%$ of $\mathrm{HCV}$ genotype 1 patients, and in $49 \%$ of uninfected controls (Thomas et al., 2009). In agreement with previous findings we found that the CC genotype was present more frequently in patients with HCV genotype 3 in comparison with patients with genotypes 1 or 4 (42.11\% and $26.92 \%$, respectively). Despite the fact that our group of patients infected with HCV genotype 3 was small, this difference was statistically significant.

All studies which analyzed SNPs near the IL28B locus emphasize the role of genetic factors in prediction of SVR. But it is interesting if earlier known and established predictors of SVR still remain independent when assessed together with this new genetic factor. In the present study we found three positive indepen- dent prognostic factors for SVR: viral genotype 3, CC genotype, and age ( $<40$ years). Neither viremia nor liver fibrosis was independently associated with SVR. In the analysis presented by McCarthy et al. (2010), similarly to our results, stage of liver fibrosis was not an independent predictive factor for SVR, yet, unlike in our study, lower viral load before the treatment predicted higher SVR. Possibly the lack of a relation between HCV viremia and SVR observed in our study was due to the fact that in analyses of small groups of patients such a relation with regard to a rather weak predictor is difficult to detect. However, results presented in some studies where the IL28B genotypes associated with treatment-induced clearance also correlated with higher baseline viral loads are very intriguing (Ge et al., 2009). This phenomenon was not confirmed in our study.

Another challenging population in which virologic response to the therapy is decreased includes patients with chronic hepatitis $\mathrm{C}$ who are co-infected with HIV. The most important prognostic factors associated with SVR among HIV/HCV co-infected patients treated with Peg-IFN- $\alpha$ plus ribavirin are similar to those observed in patients with HCV mono-infection (Fried et al., 2002). New data suggest that, like in HCV mono-infected patients, rs12979860 and rs8099917 IL 28B polymorphisms play an important role in predicting SVR in this population, particularly in patients with genotype $1 \mathrm{HCV}$ infection (Rallón et al., 2011).

There are other factors specific for $\mathrm{HIV} / \mathrm{HCV}$ coinfected patients which can influence the results of the treatment with Peg-IFN- $\alpha$ and ribavirin. These factors, including HIV viremia, CD4 count before the treatment, nadir CD4 count, were not a subject of this study (Chung et al., 2011; Myers et al., 2004). To reduce the influence of these factors, we analyzed HIV/HCV co-infected patients on cART with undetectable HIV viremia and with CD4 count higher than 350 cells/ $\mu$ l.

The obtained results indicating that in patients included in the study the rate of SVR in HIV/HCV co-infected patients was higher than in mono-infected patients (69.70\% vs $54.44 \%)$ were surprising.

These findings are in opposition to other studies where SVR occurred less frequently in co-infected patients than in HCV mono-infected ones (Torriani et al., 2004; Gonvers et al., 2010).

However, in the present study HIV/HCV co-infected patients were more frequently younger than 40 years of age, infected with genotype 3 of HCV and had the CC IL28 genotype. The more frequent occurrence of these three positive predictive factors for SVR can explain so good results of treatment in the co-infected patients in our study.

We believe that our results point out that in the treatment of $\mathrm{HIV} / \mathrm{HCV}$ co-infected patients (who are on successful antiretrovarial treatment) the most important factors for SVR are the same as in mono-infected patients and the results of the treatment with Peg-IFN- $\alpha$ and ribavirin in this group of patients can be very good.

\section{CONCLUSIONS}

These data suggest that age, HCV genotype and IL $28 \mathrm{~B}$ polymorphism are useful for prediction of the response to treatment with Peg-IFN- $\alpha$ and ribavirin. More frequent occurrence of $\mathrm{HCV}$ genotypes 3 and 4 in patients with co-infection could be associated with the route of transmission. 


\section{Acknowledgments}

We gratefully acknowledge: Anna Dabrowicz, M.D., for histological analysis of liver bioptates and Grażyna Lipowczan, M.D., Ph.D., for assessment of HCV and HIV viral load and HCV genotypes.

\section{REFERENCES}

Aziz H, Gil ML, Waheed Y, Adeeb U, Raza A, Bilal I, Athar MA (2011) Evaluation of prognostic factors for Peg Interferon alfa-2b plus ribavirin treatment on $\mathrm{HCV}$ infected patients in Pakistan. Infect Genet Evol 11: 640-645.

Batts KP, Ludwig J (1995) Chronic hepatitis. An update on terminology and reporting. Am J Surg Pathol 19: 1409-1417.

Chen SL, Morgan TR (2006) The natural history of hepatitis C virus (HCV) infection. Int J Med Sci 3: 47-52.

Chung RT, Andersen J, Volberding P, Robbins GK, Liu T, Sherman KE, Peters MG, Koziel MJ, Bhan AK, Alston B, Colquhoun D, Nevin T, Harb G, van der Horst C; AIDS Clinical Trials Group A5071 Study Team (2004) Peginterferon Alfa-2a plus ribavirin versus interferon alfa-2a plus ribavirin for chronic hepatitis $\mathrm{C}$ in HIVcoinfected persons. N Engl J Med 29: 451-459.

Eslam M, López-Cortés LF, Romero-Gomez M (2011) The role of insulin resistance in HIV/hepatitis C virus-coinfected patients. Curr Opin HIV AIDS 6: 553-558.

Fried M, Hadziyannis S (2004) Treatment of chronic hepatitis C infection with peginterferons plus ribavirin. Semin Liver Dis 24: 47-54.

Fried MW, Shiffman ML, Reddy KR, Smith C, Marinos G, Gonçales FL Jr, Häussinger D, Diago M, Carosi G, Dhumeaux D, Craxi A, Lin A, Hoffman J, Yu J (2002) Peginterferon alfa-2a plus ribavirin for chronic hepatitis C virus infection. N Engl J Med 26: 975-982.

Gonvers JJ, Heim MH, Cavassini M, Müllhaupt B, Genné D, Bernasconi E, Borovicka J, Cerny A, Chave JP, Chuard C, Dufour F, Dutoit V, Malinverni R, Monnat M, Negro F, Troilliet N, Oneta C (2010) Treatment of hepatitis C in HCV mono-infected and in HIV-HCV co-infected patients: an open-labelled comparison study. Swiss Medical Weekly 14: 1-19.

Ge D, Fellay J, Thompson AJ, Simon JS, Shianna KV, Urban TJ, Heinzen EL, Qiu P, Bertelsen AH, Muir AJ, Sulkowski M, McHutchison JG, Goldstein DB (2009) Genetic variation in IL28B predicts hepatitis C treatment-induced viral clearance. Nature 461: 399-401.

Hadziyannis SJ, Sette H Jr, Morgan TR, Balan V, Diago M, Marcellin P Ramadori G, Bodenheimer H Jr, Bernstein D, Rizzetto M, Zeuzem S, Pockros PJ, Lin A, Ackrill AM; PEGASYS International Study Group (2004) Peginterferon-alpha2a and ribavirin combination therapy in chronic hepatitis C: a randomized study of treatment duration and ribavirin dose. Ann Intern Med 2: 346-355.

Idrees M, Riazuddin S (2009) A study of best positive predictors for sustained virologic response to interferon alpha plus ribavirin therapy in naive chronic hepatitis C patients. BMC Gastroenterol 20: 5.

Kawaoka T, Hayes CN, Ohishi W, Ochi H, Maekawa T, Abe H, Tsuge M, Mitsui F, Hiraga N, Imamura M, Takahashi S, Kubo M, Tsunoda T, Nakamura Y, Kumada H, Chayama K (2011) Predictive value of the IL $28 B$ polymorphism on the effect of interferon therapy in chronic hepatitis $\mathrm{C}$ patients with genotypes $2 \mathrm{a}$ and $2 \mathrm{~b}$. I Hepatol 54: 408-414.

Koziel M, Peters M (2007) Viral hepatitis in HIV infection. N Engl J Med 356: 1445-1454.

Lauer GM, Walker BD (2001) Hepatitis C virus infection. N Engl J Med 345: 41-52.

McCarthy JJ, Li JH, Thompson A, Suchindran S, Lao XQ, Patel K, Tillmann HL, Muir AJ, McHutchison JG (2010) Replicated association between an IL 28B gene variant and a sustained response to pegylated interferon and ribavirin.Gastroenterology 138: 2307-2314.
Mangia A, Thompson AJ, Santoro R, Piazzolla V, Tillmann HL, Patel K, Shianna KV, Mottola L, Petruzzellis D, Bacca D, Carretta V, Minerva N, Goldstein DB, McHutchison JG (2010) An IL28B polymorphism determines treatment response of hepatitis $C$ virus genotype 2 or 3 patients who do not achieve a rapid virologic response. Gastroenterology 139: 821-827.

Myers RP, Benhamou Y, Bochet M, Thibault V, Mehri D, Poynard T (2004) Pegylated interferon alpha $2 \mathrm{~b}$ and ribavirin in $\mathrm{HIV} /$ hepatitis $\mathrm{C}$ virus-co-infected non-responders and relapsers to IFN-based therapy. AIDS 18: 75-79.

Navaneethan U, Kemmer N, Neff GW (2009) Predicting the probable outcome of treatment in HCV patients. Therap Adv Gastroenterol 2: 287-302.

Pineda JA, Caruz A, Rivero A, Neukam K, Salas I, Camacho A, Palomares JC, Mira JA, Martínez A, Roldán C, de la Torre J, Macías J (2010) Prediction of response to pegylated interferon plus ribavirin by II 28B gene variation in patients coinfected with HIV and hepatitis C virus. Clin Infect Dis 1: 788-795.

Pockros PJ (2011) Drugs in development for chronic hepatitis C: a promising future. Expert Opin Biol Ther 11: 1611-1622.

Rallón NI, Soriano V, Naggie S, Restrepo C, Goldstein D, Vispo E Thompson A, McHutchison J, Soriano V (2011) IL28B gene polymorphisms and viral kinetics in HIV/hepatitis $\mathrm{C}$ virus-coinfected patients treated with pegylated interferon and ribavirin. AIDS 15: 1025-1033.

Rauch A, Kutalik Z, Descombes P, Cai T, Di Iulio J, Mueller T, Bochud M, Battegay M, Bernasconi E, Borovicka J, Colombo S, Cerny A, Dufour JF, Furrer H, Günthard HF, Heim M, Hirschel B, Malinverni R, Moradpour D, Müllhaupt B, Witteck A, Beckmann JS, Berg T, Bergmann S, Negro F, Telenti A, Bochud PY; Swiss Hepatitis C Cohort Study; Swiss HIV Cohort Study (2010) Genetic variation in IL28B is associated with chronic hepatitis C and treatment failure: a genome-wide association study. Gastroenterology 138: $1338-1345$.

Reddy KR, Messinger D, Popescu M, Hadziyannis SJ (2009) Peginterferon alpha-2a $(40 \mathrm{kDa})$ and ribavirin: comparable rates of sustained virological response in sub-sets of older and younger HCV genotype 1 patients. J Viral. Hepatol 16: 724-731.

Sarrazin C, Susser S, Doehring A, Lange CM, Müller T, Schlecker C, Herrmann E, Lötsch J, Berg T (2011) Importance of IL28B gene polymorphisms in hepatitis $C$ virus genotype 2 and 3 infected patients. J Hepatol 2: 415-421.

Suppiah V, Moldovan M, Ahlenstiel G Weltman M, Abate ML, Bassendine M, Spengler U, Dore GJ, Powell E, Riordan S, Sheridan D, Smedile A, Fragomeli V, Müller T, Bahlo M, Stewart GJ, Booth DR, George J (2009) IL28B is associated with response to chronic hepatitis C interferon-alpha and ribavirin therapy. Nat Genet 41: $1100-1104$.

Tanaka Y, Nishida N, Sugiyama M, Kurosaki M, Matsuura K, Sakamoto N Nakagawa M, Korenaga M, Hino K, Hige S, Ito Y, Mita E, Tanaka E, Mochida S, Murawaki Y, Honda M, Sakai A, Hiasa Y, Nishiguchi S, Koike A, Sakaida I, Imamura M, Ito K, Yano K, Masaki N, Sugauchi F, Izumi N, Tokunaga K, Mizokami M (2009) Genome-wide association of IL28B with response to pegylated interferon-alpha and ribavirin therapy for chronic hepatitis C. Nat Genet 41: 1105-1109.

Thomas DL, Thio CL, Martin MP, Qi Y, Ge D, O'Huigin C, Kidd J, Kidd K, Khakoo SI, Alexander G, Goedert JJ, Kirk GD, Donfield SM, Rosen HR, Tobler LH, Busch MP, McHutchison JG, Goldstein DB, Carrington M (2009) Genetic variation in IL28B and spontaneous clearance of hepatitis C virus. Nature 8: 780-798.

Torriani FJ, Rodriguez-Torres M, Rockstroh JK, Lissen E, GonzalezGarcía J, Lazzarin A, Carosi G, Sasadeusz J, Katlama C, Montaner J, Sette H Jr, Passe S, De Pamphilis J, Duff F, Schrenk UM, Dieterich DT; APRICOT Study Group (2004) Peginterferon Alfa-2a plus ribavirin for chronic hepatitis $\mathrm{C}$ virus infection in $\mathrm{HIV}$-infected patients. N Engl J Med 29: 438-450. 
